\title{
Implementation of Adaptive Fuzzy Logic Control Based MPPT for Photovoltaic System
}

\author{
A. Bharathi Sankar ${ }^{1}$ and R. Seyezhai ${ }^{2}$ \\ ${ }^{1}$ Research Scholar, Dept of EEE, SSN College of Engineering, Kalavakkam, \\ Chennai-603110 \\ ${ }^{2}$ Associate professor, Dept of EEE, SSN College of Engineering, Kalavakkam, \\ Chennai-603110
}

\begin{abstract}
Recently, photovoltaic (PV) system has emerged as a promising renewable energy source to meet out the increasing energy demand. This PV cell has to optimally operate at a particular point to deliver maximum power called maximum power point (MPP). This paper presents an adaptive fuzzy logic control (AFLC) for the maximum power point tracking (MPPT) algorithm for photovoltaic power generation system. The main idea of the proposed algorithm is the application of fuzzy controller with an adaptive gain as a maximum power point tracker. It adjusts the duty cycle of the boost converter as well as controller's gain. The performance of AFLC is compared with the conventional fuzzy controller for varying irradiance. Simulation studies of AFLC are carried out in $M A T L A B$. The experimental results show the effectiveness and feasibility of the proposed controller and the results were verified. The results reveal that the adaptive FLC can quickly track change of MPP in different light intensity and deliver more power compared to the classical fuzzy logic controller.
\end{abstract}

Keywords: Photovoltaic system, Maximum Power Point Tracking, Adaptive Fuzzy Logic Control

\section{Introduction}

Among the renewable energy systems, Solar PV have gained attention as it provides a clean and inexhaustible source of energy to meet out the energy demand. But tracking the maximum power point (MPP) of a PV array is an essential part in PV systems. The purpose of maximum power point tracker (MPPT) is to ensure that the PV panel runs at its maximum efficiency by operating it at MPP under varying insolation and temperature [1-2]. Many tracking control strategies have been proposed such as perturb and observe ( $\mathrm{P}$ $\& \mathrm{O}$ ), incremental conductance (INC), constant voltage, feedback voltage or current method, neural network and fuzzy logic control [3-4]. All these strategies may vary in terms of complexity, type of implementation (analog or digital), convergence speed, accuracy and tracking ability and cost. The $\mathrm{P} \& \mathrm{O}$ algorithm actually tracks the peak power by either increasing or decreasing the array terminal voltage, or current, at regular intervals and then comparing the PV output power with that of the previous sample point [5-6].But it suffers from poor efficiency at low irradiation due to slow MPP tracking under varying insolation. This is overcome in incremental conductance (INC) algorithm which searches for the voltage operating point at which the conductance is equal to the incremental conductance [7-8]. The advantage of INC is it is capable of tracking the MPP more precisely and exhibits less oscillatory behavior around the MPP compared to the $\mathrm{P}$ $\& \mathrm{O}$ method. But the disadvantage is that the results may be unsatisfactory due to its unstable behavior at low insolation levels [9-10].The constant voltage (CV) algorithm is simple but it cannot locate the exact MPP practically but preferred for low levels of insolation [11-12].The feedback voltage or current method employs a feedback control 
loop but it cannot consider the effect of variations in insolation and temperature [13].In order to track MPPT accurately, neural network is employed but the performance of the PV system is entirely based on how well a neural network has been initially trained [14].To further improve the tracking of PV power, a fuzzy logic controller is reported in the literature which does not require the mathematical model of PV [15]. But the effectiveness of this method depends on user knowledge and skill in choosing the correct rule base table which depends on the chosen membership functions [16]. To overcome the drawbacks of all the above mentioned methods, an adaptive fuzzy logic controller is proposed in this paper.

The proposed AFLC can re-adjust fuzzy parameter to obtain optimum performance and it is less dependent on the expert knowledge. AFLC comprises two sections: the first section is the fuzzy knowledge base controller and the second one is the adaptive mechanism. Fuzzy knowledge base controller involves fuzzification, inference and defuzzification. Adaptive mechanism modifies the fuzzy logic controller so that it operates close to the optimum operating point. The main feature of AFLC is that it is able to adapt the fuzzy parameters in order to get fast response, good transient performance and insensitive to variations in external disturbances. Simulation of the proposed MPPT controller with PV modeling is implemented in MATLAB/SIMULINK. Design and implementation of AFLC based MPPT which is interfaced with a DC-DC boost converter is presented. SPARTAN/FPGA is employed to implement the proposed algorithm. The simulation results are verified experimentally. The results show that AFLC provides a higher peak power compared to FLC.

The paper is organized as follows: Section II deals with the PV model and its characteristics; section III explains the proposed adaptive fuzzy MPPT and comparison with FLC. Section IV introduces the FPGA implementation of AFLC with practical results; finally, section $\mathrm{V}$ discusses the conclusion and future work.

\section{Modeling of Solar Cell}

The solar cells are made of semiconductor material with a p-n junction fabricated in a thin wafer layer. These cells, when exposed to light, a photo current proportional to the solar radiation is generated, if the photon energy is greater than the band gap. In the dark, the I-V characteristics of a solar cell have an exponential characteristic similar to that of a diode [17]. In order to maximize the output power from a PV cell with the help of MPPT control, the modeling of PV cell is necessary [18]. The ideal equivalent circuit of a solar cell is a current source in parallel with a single-diode. The configuration of the solar cell with single-diode model is shown in Figure 1.

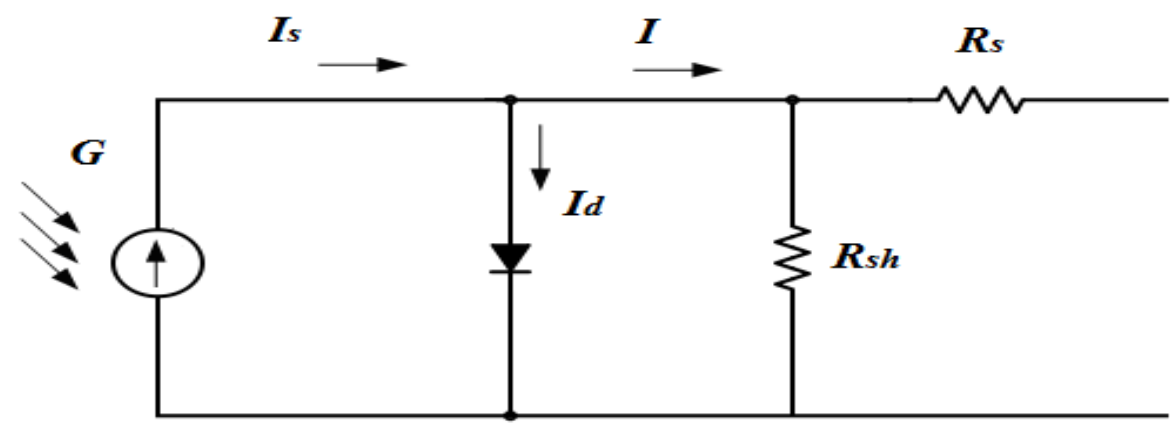

Figure 1. Model of a Solar Cell

In Figure 1, $G$ denotes the solar radiance, $I_{s}$ represents the photo generated current, $I_{d}$ is the diode current, $I$ is the output current, and $V$ is the terminal voltage. The I-V characteristics of the ideal solar cell with single diode is given by: 
$I=I_{S}-I_{o}\left[e^{\frac{q V}{m k T}}-1\right]$

where $I_{o}$ is the diode reverse bias saturation current, $q$ is the electron charge, $m$ is the diode ideality factor, $k$ is the Boltzmann's constant, and $T$ is the cell temperature.

A solar cell is characterized by the short circuit current $I_{s c}$, the open circuit voltage $V_{o c}$, and the diode ideality factor $m$. For the same irradiance and $p$ - $n$ junction temperature conditions, the short circuit current $\mathrm{I}_{\mathrm{sc}}$ is the maximum value of the current generated by the cell. It is given by:

$I_{s c}=I=I_{s}$ for $V=0$

For the same irradiance and $p-n$ junction temperature conditions, the open circuit voltage $V_{o c}$ is the highest value of the voltage that appears at the cell terminals. It is given by:

$V=V_{o c}=\frac{m k T}{q} \ln \left(I+\frac{I_{s c}}{I_{o}}\right) \quad$ for $I=0$

The output power is given by:

$P=V\left[I_{s c}-I_{o}\left[e^{\frac{q V}{m k T}}-1\right]\right]$

Table 1, shows that electrical characteristics of PV array, extracted from manufacturer data which is used for the modeling of PV in Simulink.

Table 1. Specification of PV Panel

\begin{tabular}{|c|c|}
\hline $\mathbf{V}_{\text {oc }}$ & $31.16 \mathrm{~V}$ \\
\hline $\mathbf{I}_{\mathbf{s c}}$ & $8.57 \mathrm{~A}$ \\
\hline $\mathbf{P}_{\max }$ & $250 \mathrm{~W}$ \\
\hline Insolation W/m & $1000 \mathrm{~W} / \mathrm{m}^{2}$ \\
\hline FF (Fill Factor) & $76.72 \%$ \\
\hline
\end{tabular}

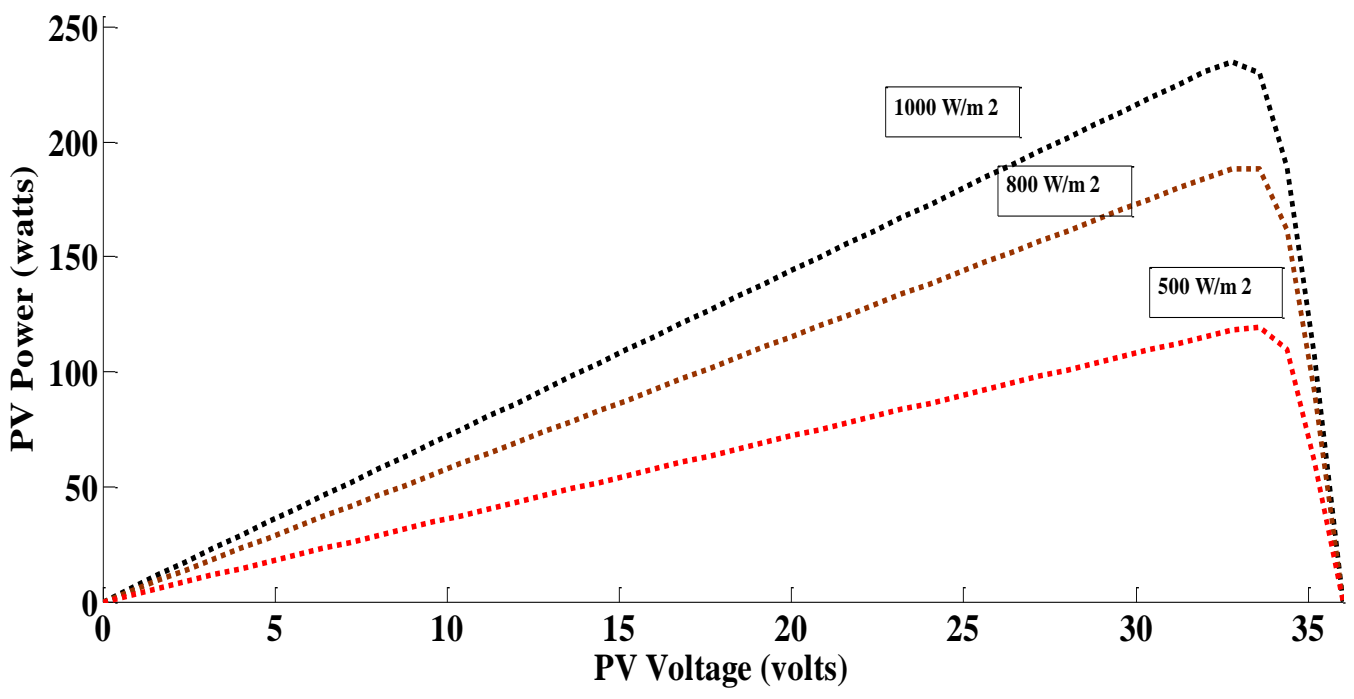

Figure 2. PV Characteristics for Variable Irradiance 


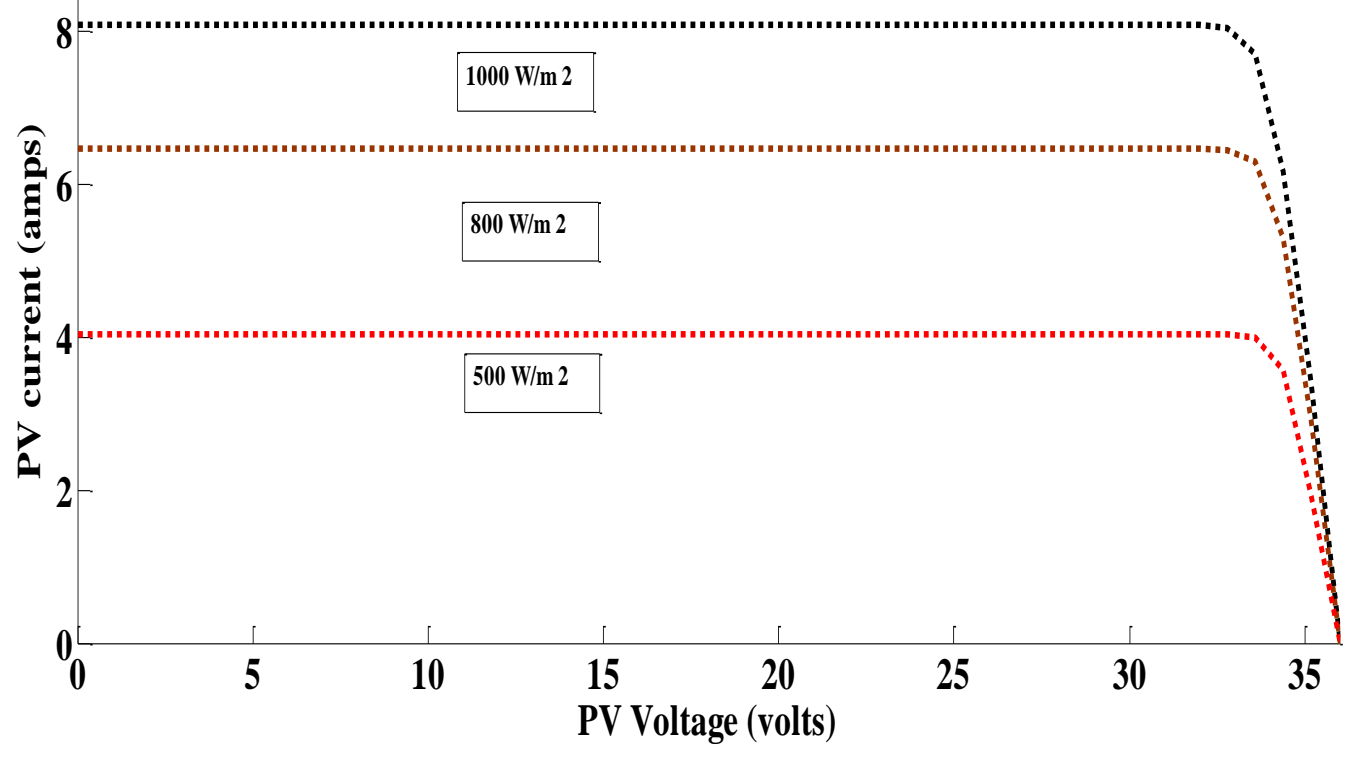

Figure 3. VI Characteristics for Variable Irradiance

The PV and VI characteristics for varying irradiation at constant temperature is shown in Figures 2 and 3. When the irradiation increases, the output current increases and the output voltage also increases. This results in net increase in output power with increase in irradiation at constant temperature.

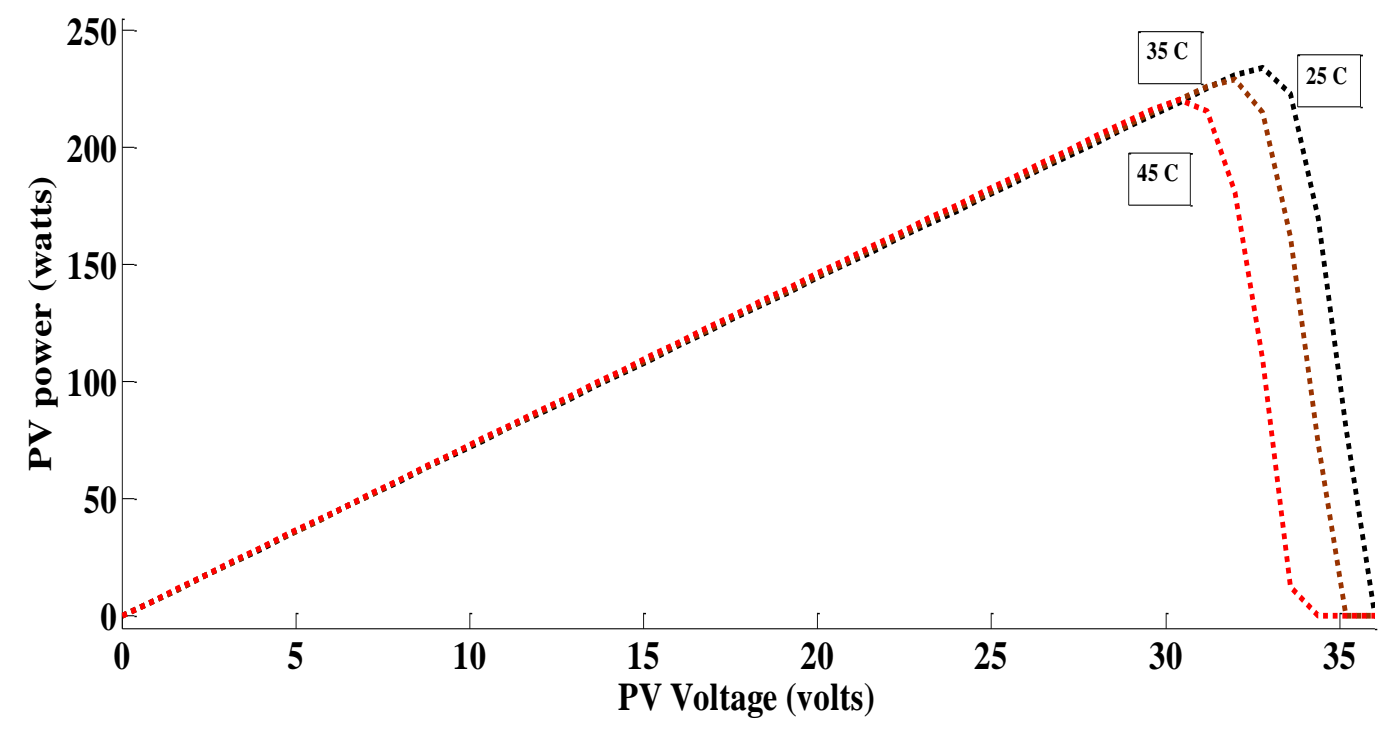

Figure 4. PV Characteristics for Variable Temperature 


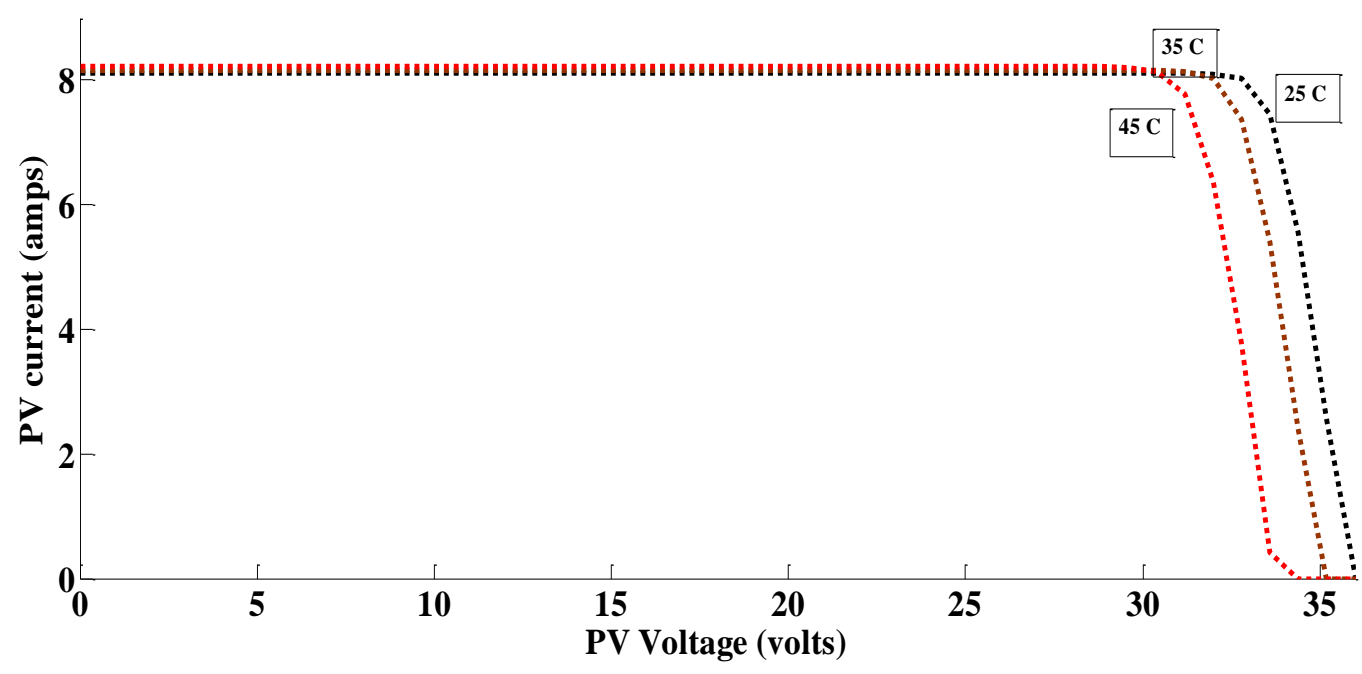

Figure 5. IV Characteristics for Variable Temperature

The PV power and current with varying temperature at constant irradiation is shown in Figures 4 , and 5. When the operating temperature increases, the output current increases marginally but the output voltage decreases drastically resulting in net reduction in output power with rise in temperature.

\section{Proposed Adaptive Fuzzy Logic Controller (AFLC) MPPT Technique}

In this section, the AFLC controller for MPPT is discussed, and the goal is to maximize the output power of PV [19-20]. Fuzzy logic control MPPT with fixed parameters are inadequate in applications where the operating condition changes in a wide range and available expert knowledge is not reliable. To make the controller less dependent on expert knowledge, the adaptive fuzzy logic control is proposed. The proposed AFLC is improved from scaling FLC, and it is mainly to adjust the duty-cycle of the defuzzification of FLC for external variations and solar irradiance. It can re-adjust fuzzy parameter to obtain optimum performance. According to voltage $\left(\mathrm{V}_{\mathrm{PV}}\right)$ and current $\left(\mathrm{I}_{\mathrm{PV}}\right)$ of PV module, the duty cycle D will be determined through the AFLC controller in order to realize MPPT [21-22]. The structure of the proposed AFLC controller is shown in Figure 6, and it contains two parts: (i) fuzzy logic control and (ii) adaptive mechanism.

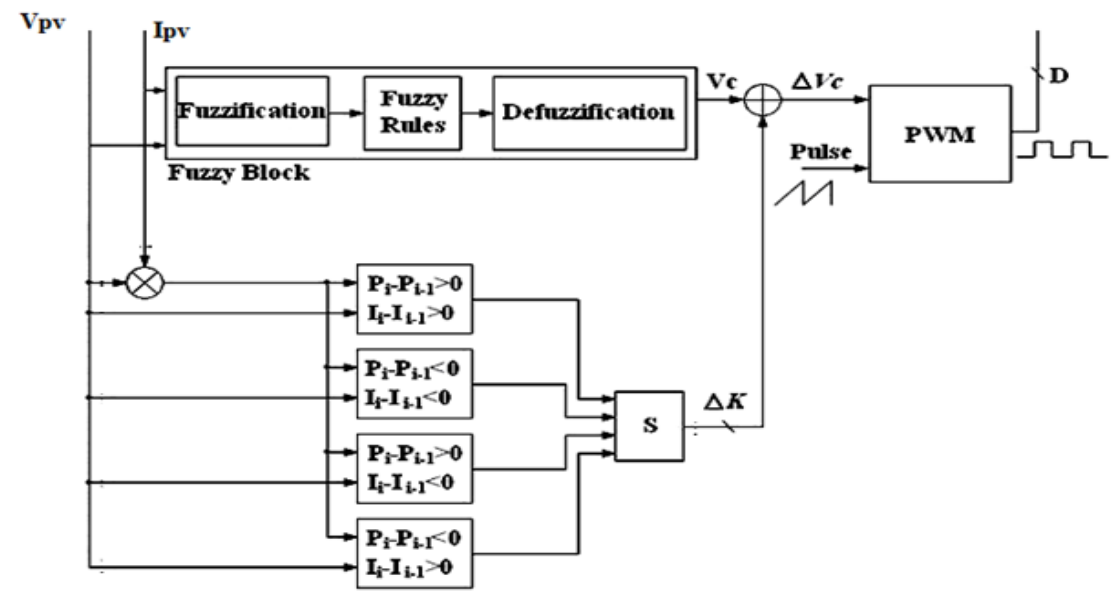

Figure 6. Structure of Adaptive Fuzzy Logic Controller 


\subsection{Fuzzy Logic Control}

The FLC is composed of three units: (a) fuzzification, (b) fuzzy rules, (c) defuzzification.

(a)Fuzzification: Initially, $\mathrm{V}_{\mathrm{PV}}$ and $\mathrm{I}_{\mathrm{PV}}$ of $\mathrm{PV}$ module are combined with the previous $\mathrm{V}_{\mathrm{PV}}$ and $\mathrm{I}_{\mathrm{PV}}$ for the averaged computation as:

$$
\begin{aligned}
\mathrm{V}_{\mathrm{pv}}(\mathrm{k}) & =\left[\mathrm{V}_{\mathrm{pv}}(\mathrm{k}-1)+\mathrm{V}_{\mathrm{pv}}(\mathrm{k}-2)\right] / 2 \\
\mathrm{I}_{\mathrm{pv}}(\mathrm{k}) & =\left[\mathrm{I}_{\mathrm{pv}}(\mathrm{k}-1)+\mathrm{I}_{\mathrm{pv}}(\mathrm{k}-2)\right] / 2
\end{aligned}
$$
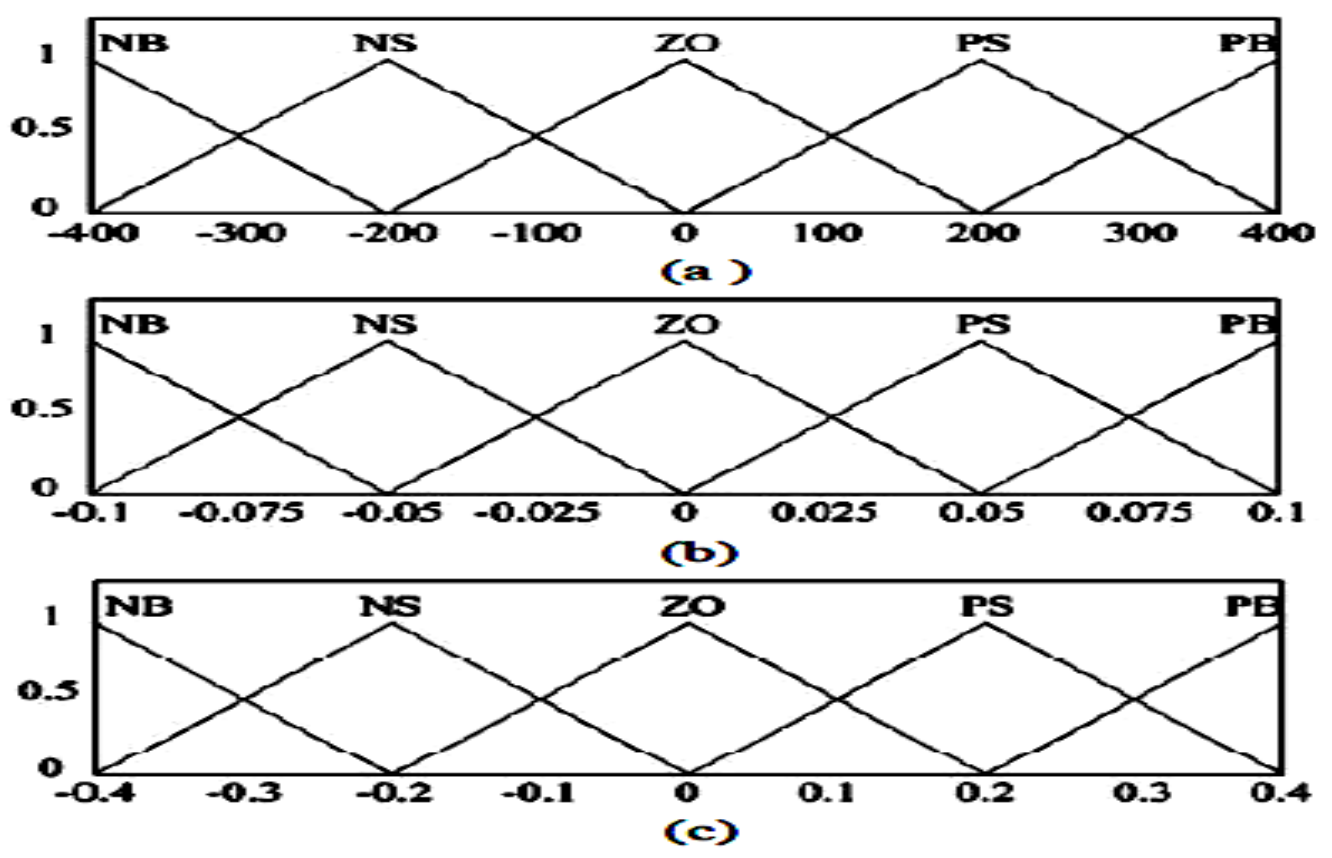

Figure 7. Membership Function (a) Input $I_{P V}(k)$, (b) Input $V_{P V}(k),(c)$ Duty Cycle

Such an average is used for the local trend estimation of $\mathrm{V}_{\mathrm{PV}}$ and $\mathrm{I}_{\mathrm{PV}}$. With the help of the trend estimation, the duty cycle can be obtained more effectively. Next, these voltage and current values are scaled and normalized into $-400 \sim 400$ and $-0.1 \sim 0.1$, and through the membership function, the related fuzzy values $(0 \sim 1)$ can be estimated for each fuzzy descriptor: NB, NS, ZO, PS, and PB (e.g., NB: negative and big, ZO: zero, and PS: positive small) as shown in Figure 7. Finally, by comparing these values, $V_{P V}$ and $I_{P v}$ can be determined and assigned to the fuzzy descriptors (NB/NS/ZP/PS/PB), which have the highest membership function values respectively.

(b) Fuzzy rules: The syntax "if-then" is always used as the expression of fuzzy rules, e.g., IF $V_{P V}$ is PS and $I_{P V}$ is NB, then D is ZO, i.e., when $V_{P V}$ is PS and $I_{P V}$ is NB, it means that $\mathrm{V}_{\mathrm{PV}}$ is higher than the voltage $\mathrm{V}_{\text {mpp }}$ on MPP with a small current $\mathrm{I}_{\mathrm{PV}}$. We directly assign the duty cycle $\mathrm{D}$ to be $\mathrm{ZO}$ for the medium-sized drive, and it is enough to make the exceeded $V_{P V}$ decreasing a little back to a suitable value. Table 2, shows that fuzzy rules to define the relationship between $\mathrm{V}_{\mathrm{PV}}$, IPV, and $\mathrm{D}$. 
Table 2. Fuzzy Rules of AFLC

\begin{tabular}{|c|c|c|c|c|c|}
\hline V/I PV & NB & NS & ZO & PS & PB \\
\hline NB & NB & NS & NS & ZO & ZO \\
\hline NS & NS & ZO & ZO & ZO & PS \\
\hline ZO & ZO & ZO & PS & PS & PS \\
\hline PS & ZO & PS & PS & PS & PB \\
\hline PB & PS & PS & PB & PB & PB \\
\hline
\end{tabular}

(c).Defuzzification: Defuzzification is for the aggregation of the duty cycle (D) from each rule, i.e., the duty cycle from fuzzy rules must be computed and combined for a specified value. The center of area (COA) defuzzification method is employed. The magnitude of duty cycle $V_{\mathrm{c}}$ is given by:

$V_{C}=\frac{\sum_{J=1}^{25} D_{j}\left(w_{j}\right) \cdot w_{j}}{\sum_{J=1}^{25} D_{j}\left(w_{j}\right)}$

Where $D_{j}$ is the duty cycle values for the $j$-th rule, and $w_{j}$ is the weighted factor of the $j$ th rule. The $w_{j}$ is bigger, the $j$-th rule affects more at this moment.

\subsection{Adaptive Mechanism}

The purpose of the adaptive mechanism is to modify the duty cycle of the defuzzification of FLC, so it makes the PV system to provide a better response time and a higher output power. The adaptive mechanism comprises three parts which is discussed as follows:

(a) First, in order to eliminate the high-frequency noise, we adopt the moving average filter to compute $\mathrm{P}_{\mathrm{PV}}$ as:

$\mathrm{P}_{\mathrm{pv}}(\mathrm{n})=\left[\mathrm{P}_{\mathrm{pv}}(\mathrm{n}-1)+\mathrm{P}_{\mathrm{pv}}(\mathrm{n}-2)\right] / 2$

The moving average filter is a good way to estimate the local trend of the signal with possible high-frequency disturbances/noise. The basic idea is by using the average computation of values within a moving window to estimate the trend change of the signal. The quality of trend estimation depends on the number of values within a window. Similarly, the sunlight intensity affects the current $\mathrm{I}_{\mathrm{PV}}$ of PV module, so this method is adopted to estimate the trend of $I_{P V}$ as:

$\mathrm{I}_{\mathrm{pv}}(\mathrm{n})=\left[\mathrm{I}_{\mathrm{pv}}(\mathrm{n}-1)+\mathrm{I}_{\mathrm{pv}}(\mathrm{n}-2)\right] / 2$

(b) Based on $P_{P V}(n)$ and $I_{P V}(n)$, plus comparing with previous $P_{P V}(n-1)$ and $I_{P V}(n-1)$, their differences can be computed. Then, it is obvious that the differences of $P_{P V}$ and $I_{P V}$ are either positive or negative, respectively. Thus, it can be summarized as four trends, and going a step further, four rules for adaptive mechanism can be suggested as shown in Table 3.

Table 3. Adaptive Mechanism of AFLC

\begin{tabular}{|c|c|c|c|c|}
\hline Rule & $\begin{array}{l}{\left[\mathrm{P}_{\mathrm{pv}}(\mathrm{n})-\mathrm{P}_{\mathrm{pv}}(\mathrm{n}-\right.} \\
1)]>0\end{array}$ & {$\left[\mathrm{I}_{\mathrm{pv}}(\mathrm{n})-\mathrm{I}_{\mathrm{pv}}(\mathrm{n}-1)\right]>0$} & Duty cycle & Select of $\Delta K$ \\
\hline 1 & True & True & \multirow{2}{*}{$\begin{array}{c}\text { decrease a } \\
\text { little }\end{array}$} & \multirow{2}{*}{$\mathrm{K}_{1}$} \\
\hline 2 & False & False & & \\
\hline 3 & True & False & \multirow{2}{*}{$\begin{array}{c}\text { Decrease a } \\
\text { lot }\end{array}$} & \multirow[t]{2}{*}{$\mathrm{K}_{2}$} \\
\hline 4 & False & True & & \\
\hline
\end{tabular}


The rules are explained in detail as follows:

(1) Rule 1 and Rule 2: A fixed parameter is inadequate in applications when the operating conditions change, and it is not reliable. Thus, the duty cycle can be modified by rule 1 and rule 2, and then the adaptive value $\Delta K$ is assigned to $\mathrm{K}_{1}=-0.25$. Because $\Delta K$ is a smaller negative value now, the duty cycle will be modified to decrease a little.

(2) Rule 3 and Rule 4: Similarly, the duty cycle can be modified by rule 3 and rule 4, and then the adaptive value $\Delta K$ is assigned to $\mathrm{K}_{2}=-0.3$. Because $\Delta K$ is a bigger negative value now, the duty cycle will be modified to decrease a lot.

(c) To combine this adaptive value $\Delta K$ and $\mathrm{V}_{\mathrm{c}}$ from defuzzification, the duty-cycle control voltage $\Delta V_{c}$ can be obtained as:

$\Delta V_{\mathrm{C}}=\mathrm{V}_{\mathrm{C}}+\Delta K$

By using the $\Delta V_{c}$, the duty cycle D is determined via the PWM block as shown in Figure. 6 , for the control of MOSFET in boost converter so as to realize the MPP search.

\section{Modeling of DC-DC Converter}

DC-DC converters are employed for generating variable DC voltage source from a fixed DC source. It is used to step up the input voltage to a required output voltage without the use of a transformer. The control strategy lies in the manipulation of the duty cycle of the switch which causes the voltage change [23]. The circuit diagram of the designed boost converter is shown in Figure 8.

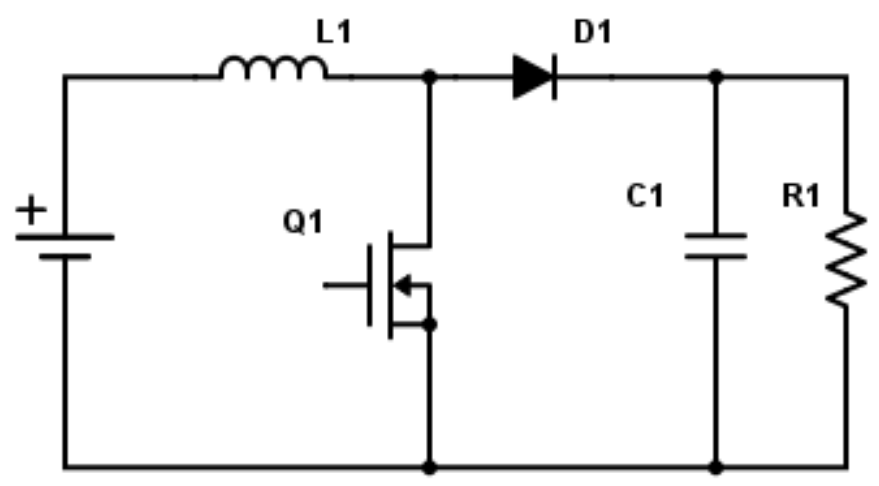

Figure 8. Circuit Diagram of Boost Converter

The operation of boost converter can be divided into two modes, Mode 1 and Mode 2 . Mode- 1 begins when MOSFET $\mathrm{Q}_{1}$ is switched on at time $\mathrm{t}=0$. The input current rises and it flows through inductor L and MOSFET as shown in Figure 9. 


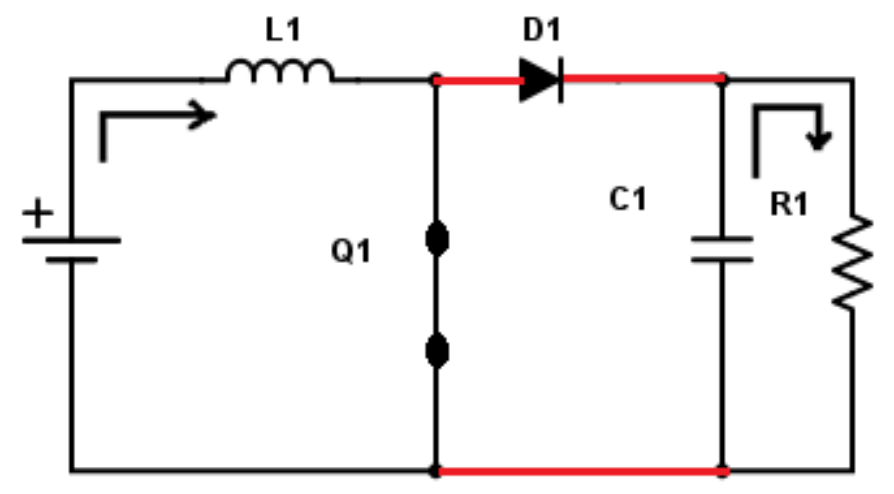

Figure 9. Equivalent Circuit for Mode-1

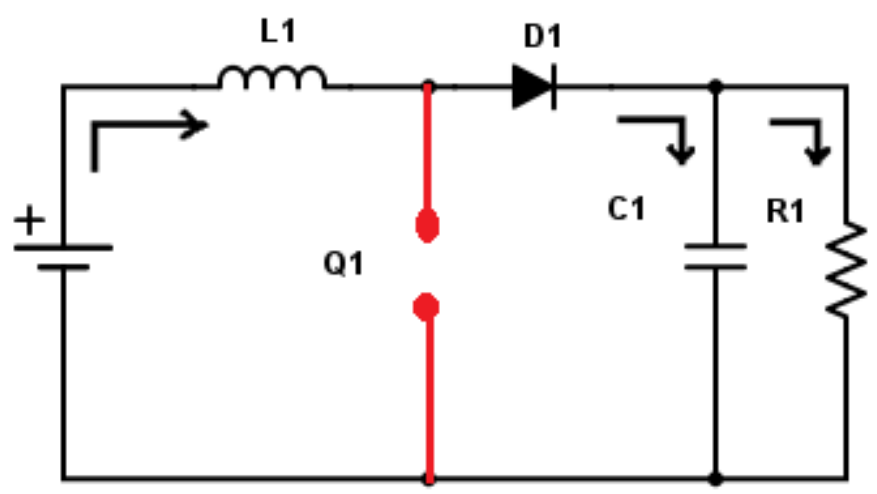

Figure 10. Equivalent Circuit for Mode-2

Mode 2 begins when MOSFET is switched off at time $t=t_{1}$. The input current now flows through $\mathrm{L}, \mathrm{C}$, load, and diode $\mathrm{D}_{1}$. The inductor current falls until the next cycle. The energy stored in inductor $\mathrm{L}$ flows through the load as shown in Figure 10.

The voltage-current relation for the inductor $\mathrm{L}$ is:

$i=\frac{1}{L} \int_{0}^{t} V d t+i_{o}$

where $i$ is the input current, $V$ is input voltage, $L$ is inductance and $i_{o}$ is the output current.

The active switch in the boost converter is a MOSFET.A fast recovery diode is used as the freewheeling diode. The principle of the boost is to excite the main switch with a duty cycle D produced by the MPPT control and when the switch is closed the inductor L is loading during T(D) time, afterwards the switch is opened, the inductor supplies the load through the diode during (1-D)T. For a DC-DC boost converter, for continuous conduction mode the equations of $\mathrm{L} \& \mathrm{C}$ are given by:

The relation between input and output voltage, inductor $\mathrm{L}$ and capacitor $\mathrm{C}$ of boost converter is given by

$V_{\text {out }}=\frac{V_{\text {in }}}{1-D} \ldots \ldots$.

$c=\frac{I_{o} * D}{f_{S} * \Delta V_{o}} \ldots \ldots$

$L=\frac{V_{s} * D}{f_{s} * \Delta I_{o}} \ldots \ldots$

where,

$I_{O}$ - Output current

$V_{S}$ - Supply voltage 


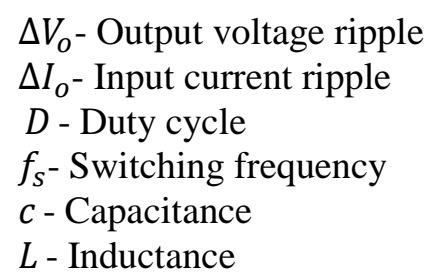

Based on the design equations, the simulation parameters for boost converter is shown in Table 4. Simulink model of the Adaptive fuzzy MPPT control based photovoltaic power generation is shown in Figure 11.

Table 4. Simulation Parameters for Boost Converter

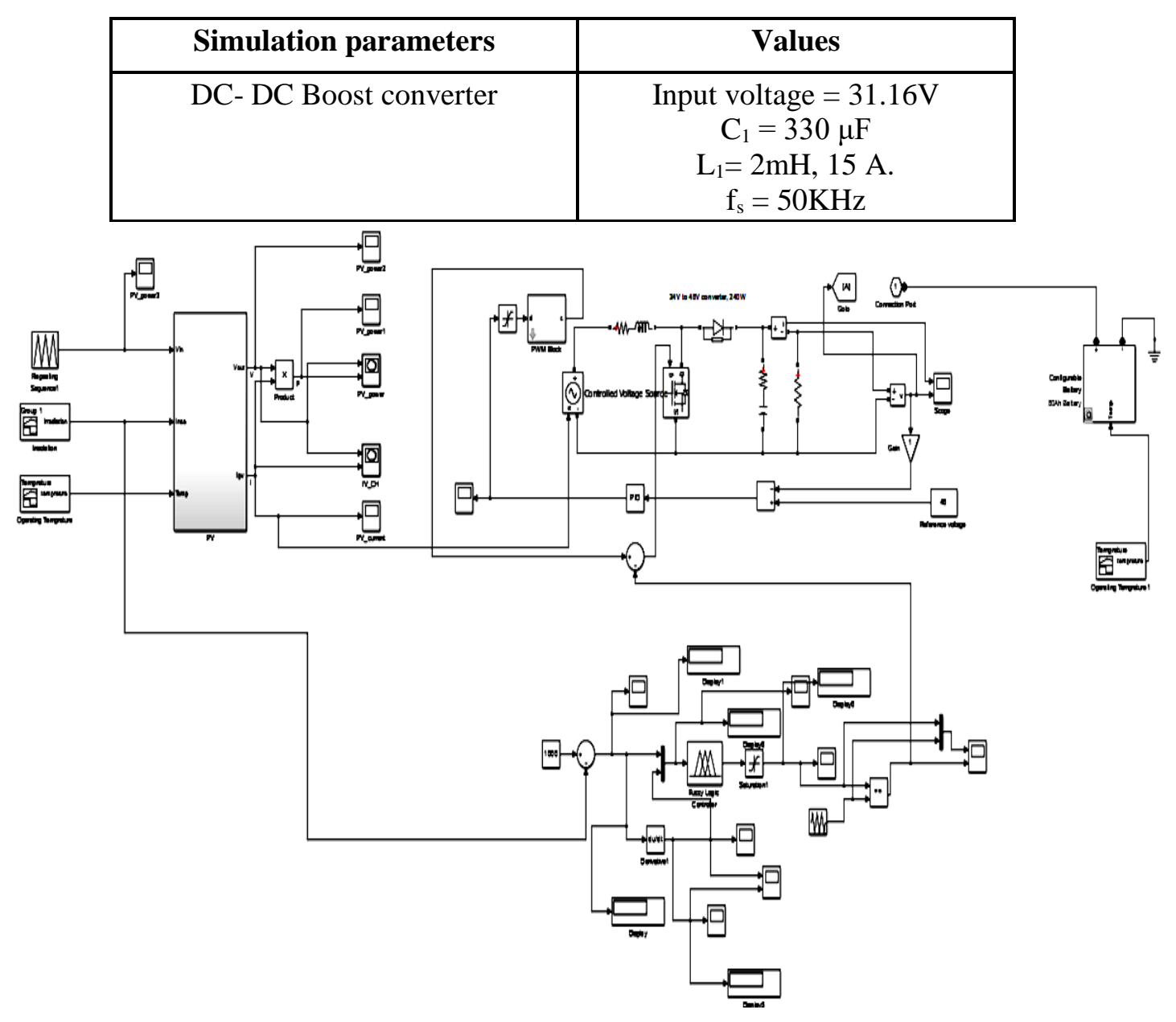

Figure 11. Simulink Model of the Adaptive fuzzy MPPT Control Based Photovoltaic Power Generation 


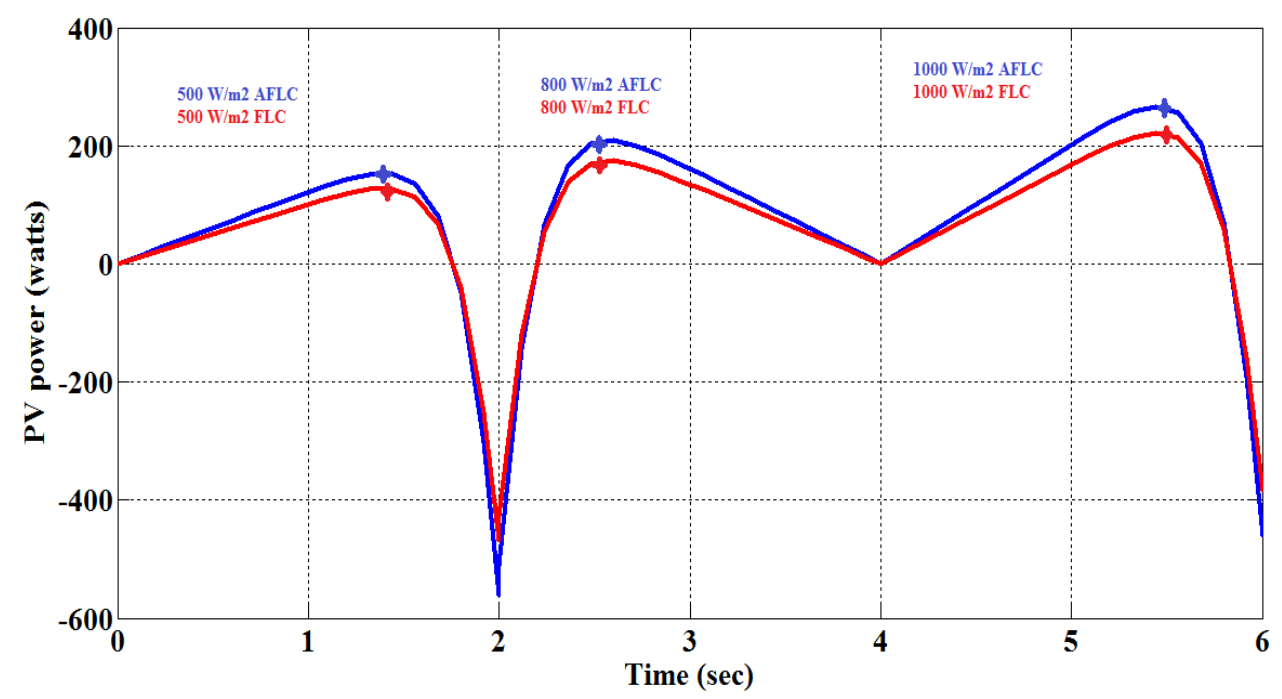

Figure 12, PV Power Using Adaptive Fuzzy Logic MPPT

Figure 12, shows the PV power using FLC \& AFLC. Using AFLC, for irradiance of $500 \mathrm{~W} / \mathrm{m} 2$, the obtained power value is about $175 \mathrm{~W}$, whereas it is $155 \mathrm{~W}$ for fuzzy logic control. Similarly, for $1000 \mathrm{~W} / \mathrm{m} 2 \& 800 \mathrm{~W} / \mathrm{m} 2$, the value of PV power is higher in AFLC compared to FLC.

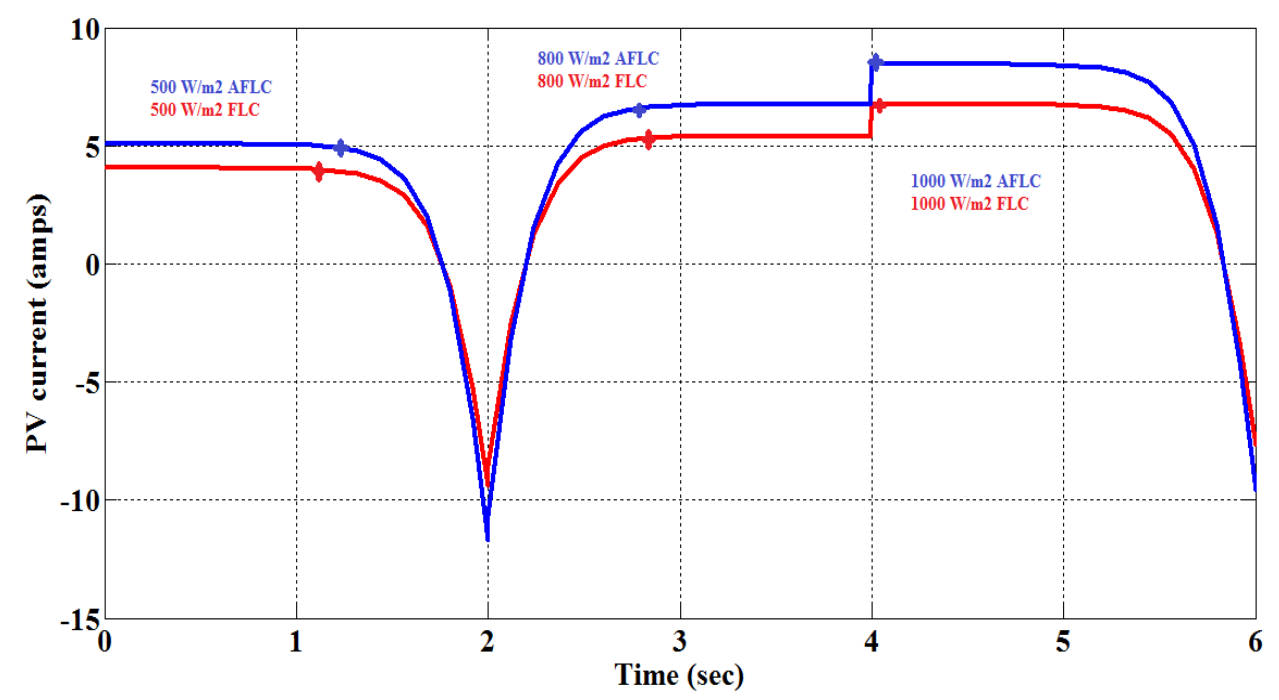

Figure 13. PV Current Using Adaptive Fuzzy Logic MPPT

Figure 13, shows the PV current using FLC \& AFLC. Using AFLC, for irradiance of $500 \mathrm{~W} / \mathrm{m} 2$, the obtained current value is about $5 \mathrm{~A}$, whereas it is $4 \mathrm{~A}$ for fuzzy logic control. Similarly, for $1000 \mathrm{~W} / \mathrm{m} 2 \& 800 \mathrm{~W} / \mathrm{m} 2$, the value of PV current is higher in AFLC compared to FLC. 


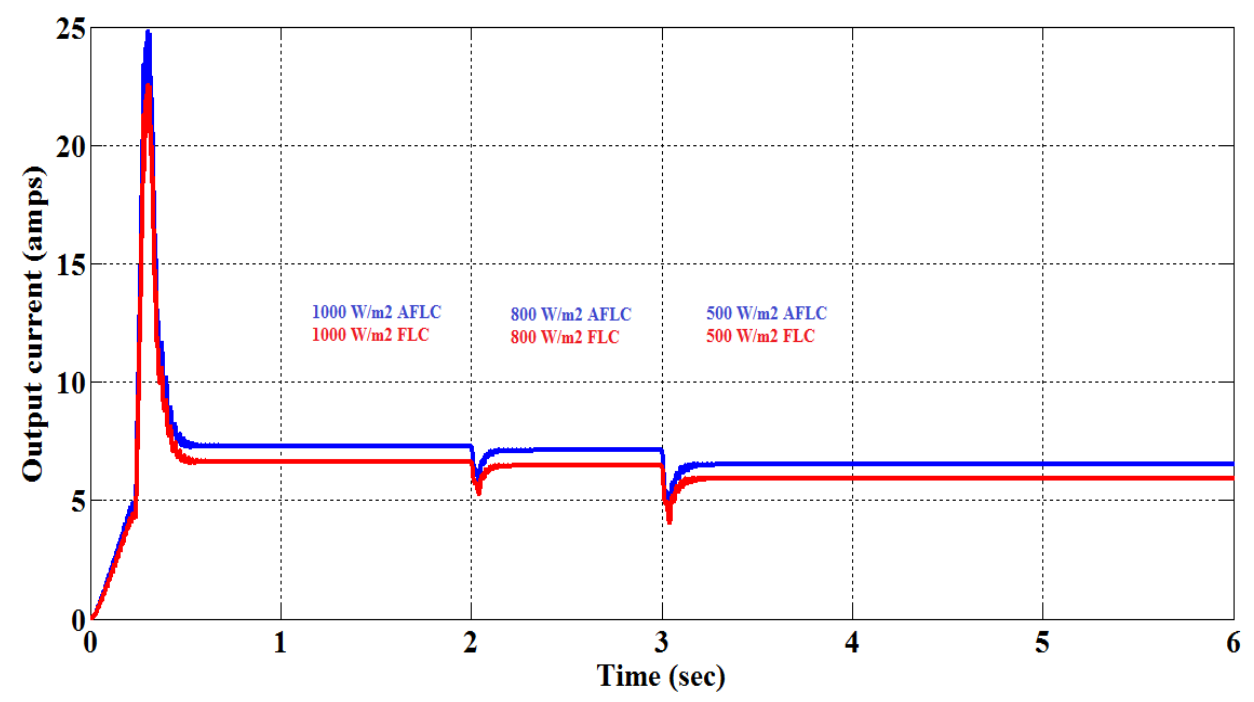

Figure 14. Converter Current Using Adaptive Fuzzy Logic MPPT

Figure 14, shows the converter current using FLC \& AFLC. Using AFLC, for irradiance of $1000 \mathrm{~W} / \mathrm{m} 2$, the obtained current value is about $7.5 \mathrm{~A}$, whereas it is $6.5 \mathrm{~A}$ for fuzzy logic control. Similarly, for $800 \mathrm{~W} / \mathrm{m} 2 \& 500 \mathrm{~W} / \mathrm{m} 2$, the value of converter current is higher in AFLC compared to FLC.

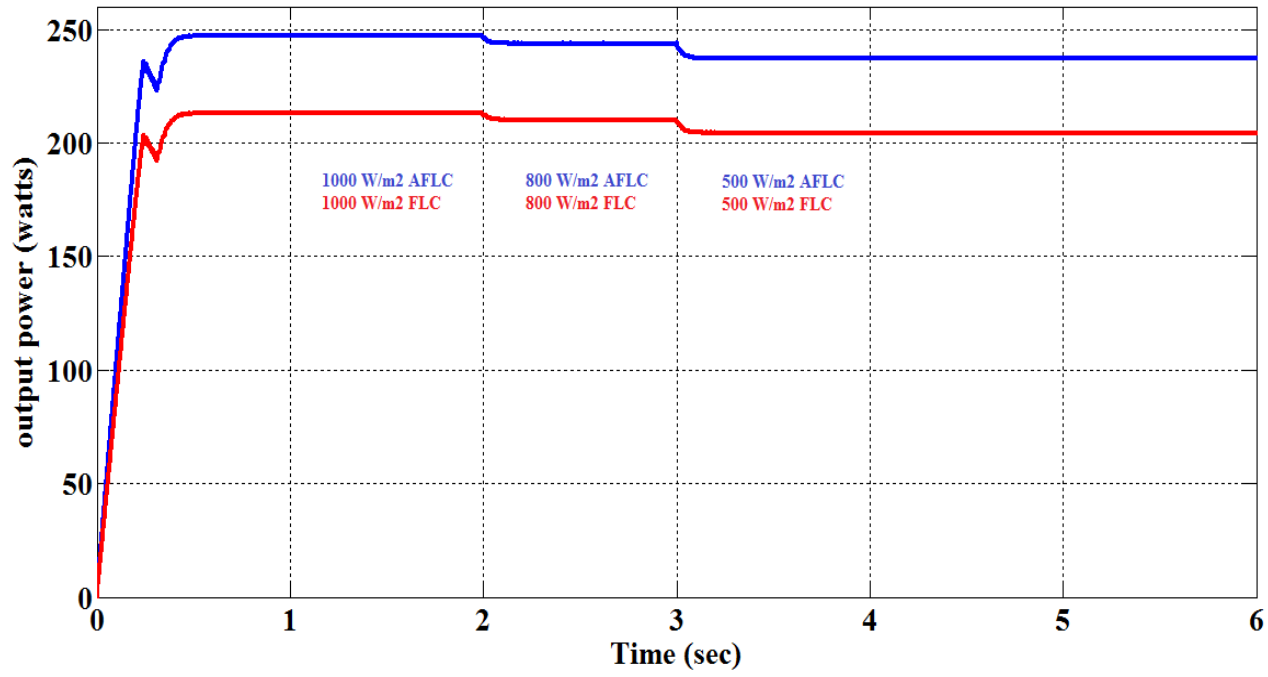

Figure 15. Converter Power Using Adaptive Fuzzy Logic MPPT

Figure 15, shows the converter power using FLC \& AFLC. Using AFLC, for irradiance of $1000 \mathrm{~W} / \mathrm{m} 2$, the obtained power value is about $250 \mathrm{~W}$, whereas it is $210 \mathrm{~W}$ for fuzzy logic control. Similarly, for $800 \mathrm{~W} / \mathrm{m} 2 \& 500 \mathrm{~W} / \mathrm{m} 2$, the value of converter power is higher in AFLC compared to FLC. 


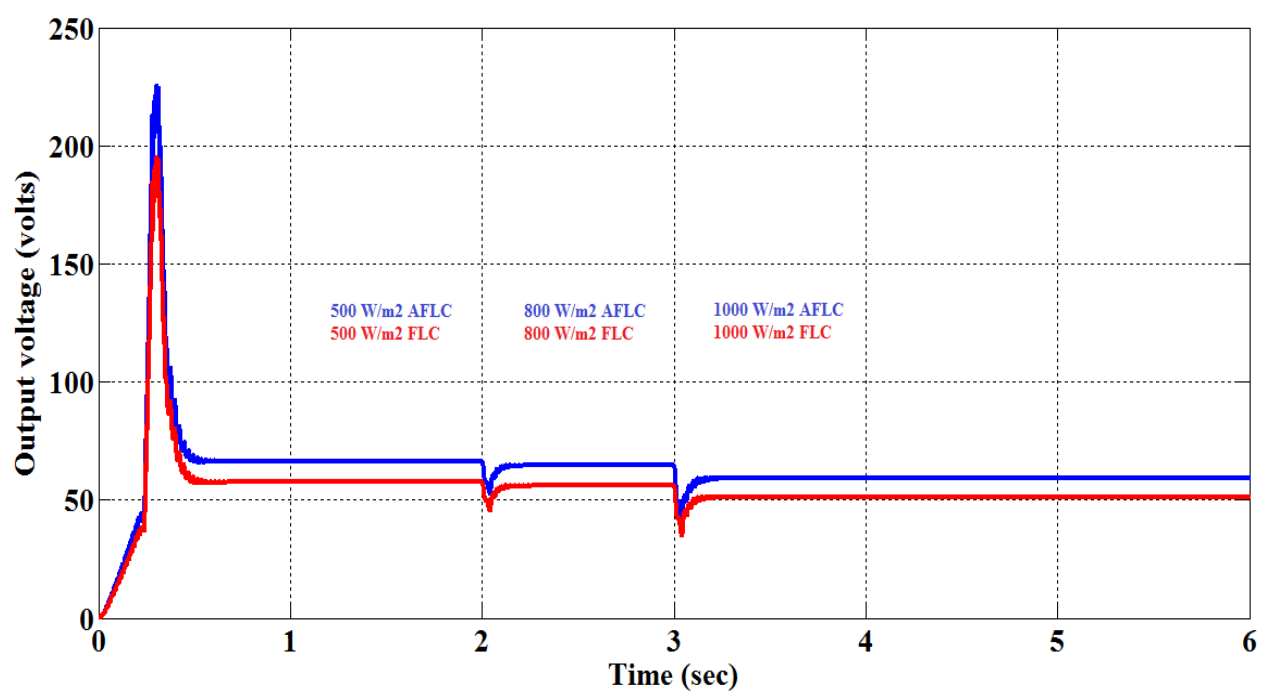

Figure 16. Converter Voltage Using Adaptive Fuzzy Logic MPPT

Figure 16, shows the converter voltage using FLC \& AFLC. Using AFLC, for irradiance of $500 \mathrm{~W} / \mathrm{m} 2$, the obtained voltage value is about $62.5 \mathrm{~V}$, whereas it is $55.5 \mathrm{~V}$ for fuzzy logic control. Similarly, for $800 \mathrm{~W} / \mathrm{m} 2 \& 1000 \mathrm{~W} / \mathrm{m} 2$, the value of converter voltage is higher in AFLC compared to FLC.

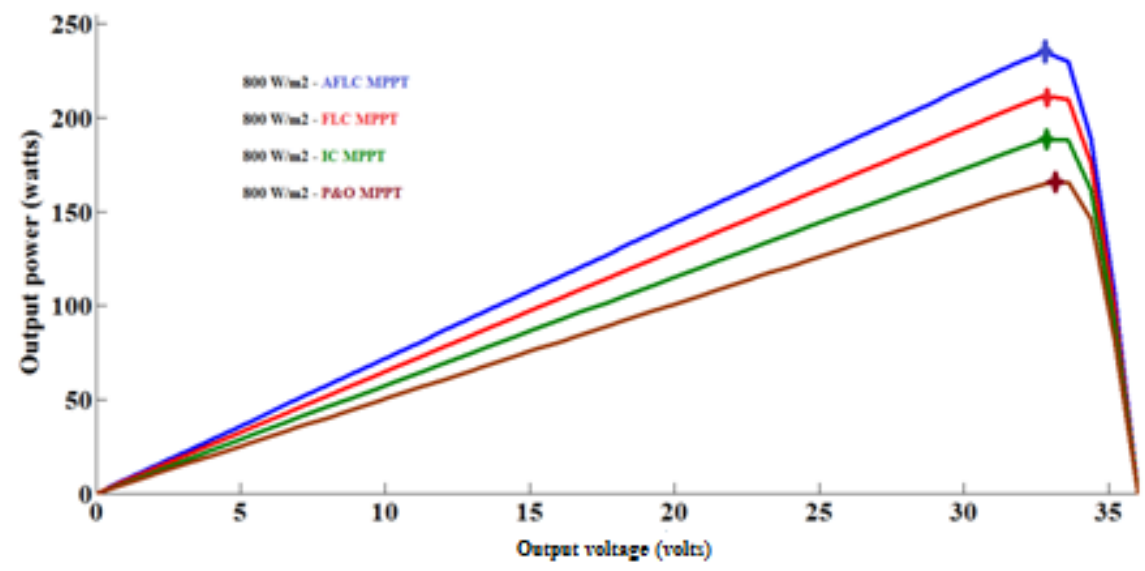

Figure 17. Converter Output Power for Various MPPT

Figure 17, shows the converter output power for FLC, IC.P \& O \&AFLC . For irradiance of $800 \mathrm{~W} / \mathrm{m} 2$, the obtained power is about $240 \mathrm{~W}$ using AFLC method, whereas it is $210 \mathrm{~W}$ for fuzzy logic control, $180 \mathrm{~W}$ for IC control and $165 \mathrm{~W}$ for P \&O, which clearly depicts that AFLC accurately tracks the PV power compared to the conventional methods. Moreover, the results highlight that the tracking efficiencies of the PV system with AFLC under all operating conditions is higher compared to the classical techniques.

\section{Experimental Setup of AFLC MPPT based Photovoltaic System}

The hardware set-up for the AFLC MPPT based PV system is shown in Figure 18. Photovoltaic panel and boost converter specifications are shown in Table 5. 


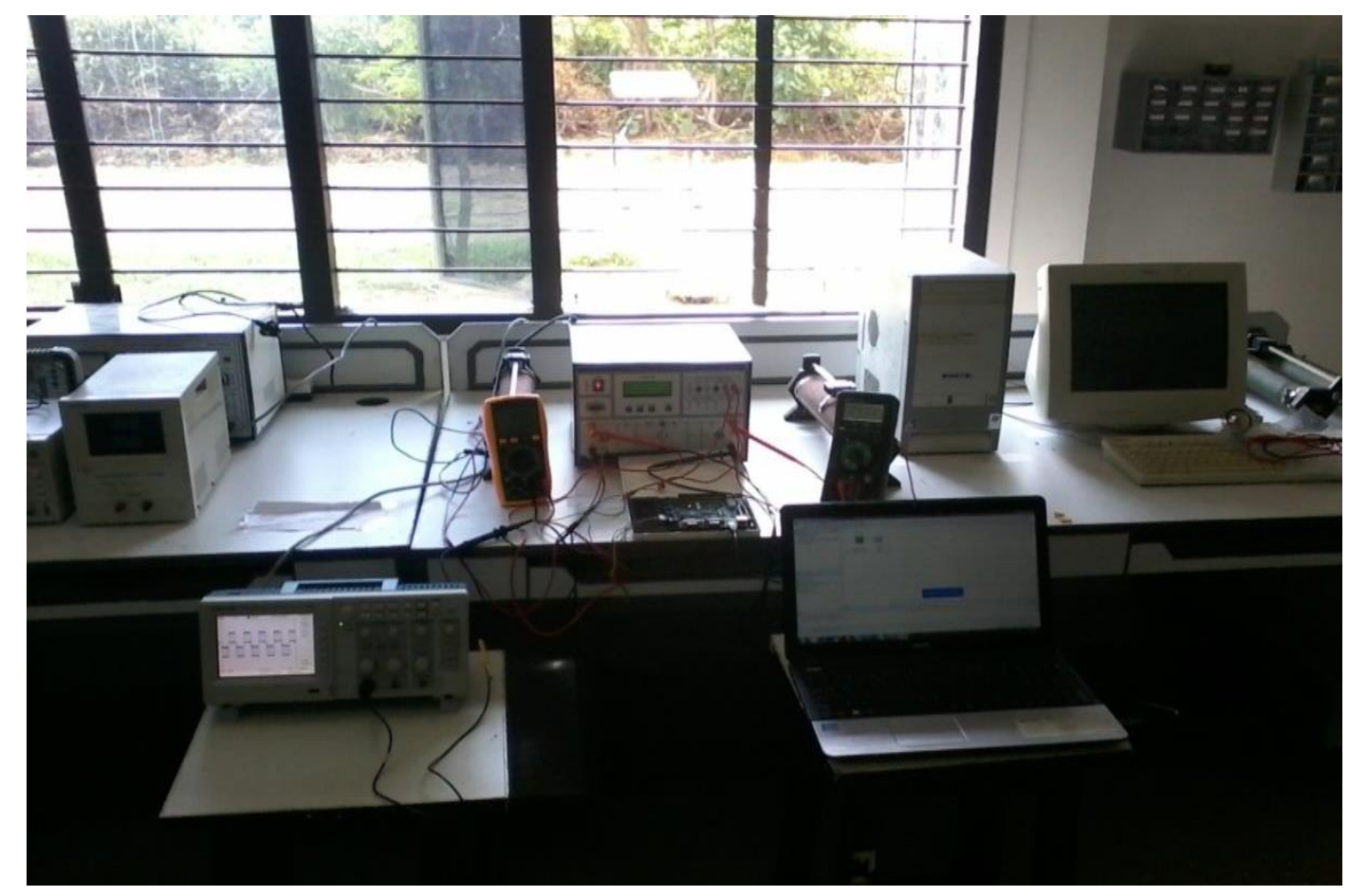

Figure 18. Hardware Set-Up for Boost Converter for PV

Table 5. Specifications of PV Panel \& Boost Converter

\begin{tabular}{|c|c|}
\hline Parameters & Values \\
\hline I/P Voltage & $31.16 \mathrm{~V}$ \\
\hline I/P Current & $8.57 \mathrm{~A}$ \\
\hline Power & $250 \mathrm{~W}$ \\
\hline Insolation W/m ${ }^{2}$ & $1000 \mathrm{~W} / \mathrm{m}^{2}$ \\
\hline Fill Factor $(\mathrm{FF})$ & $76.72 \%$ \\
\hline Output Capacitance & $\mathrm{C}_{1}=330 \mu \mathrm{F}$ \\
\hline Inductance & $\mathrm{L}_{1}=2 \mathrm{mH}, 15 \mathrm{~A}$. \\
\hline Switching Frequency & $\mathrm{f}_{\mathrm{s}}=50 \mathrm{KHz}$ \\
\hline
\end{tabular}

The experimental P-V and V-I characteristics are shown in Figure 19. 


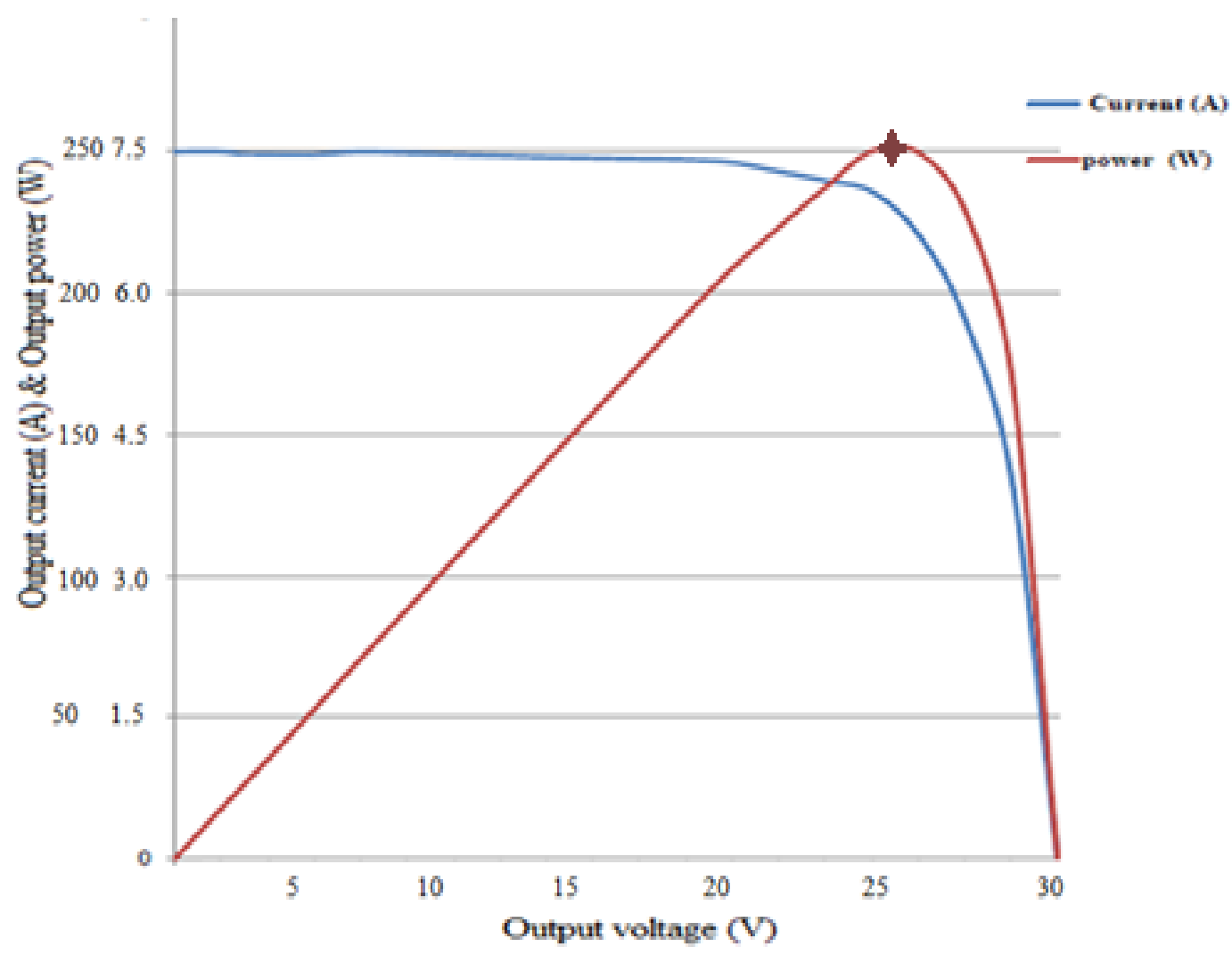

Figure 19. Experimental P-V \& V-I Characteristics

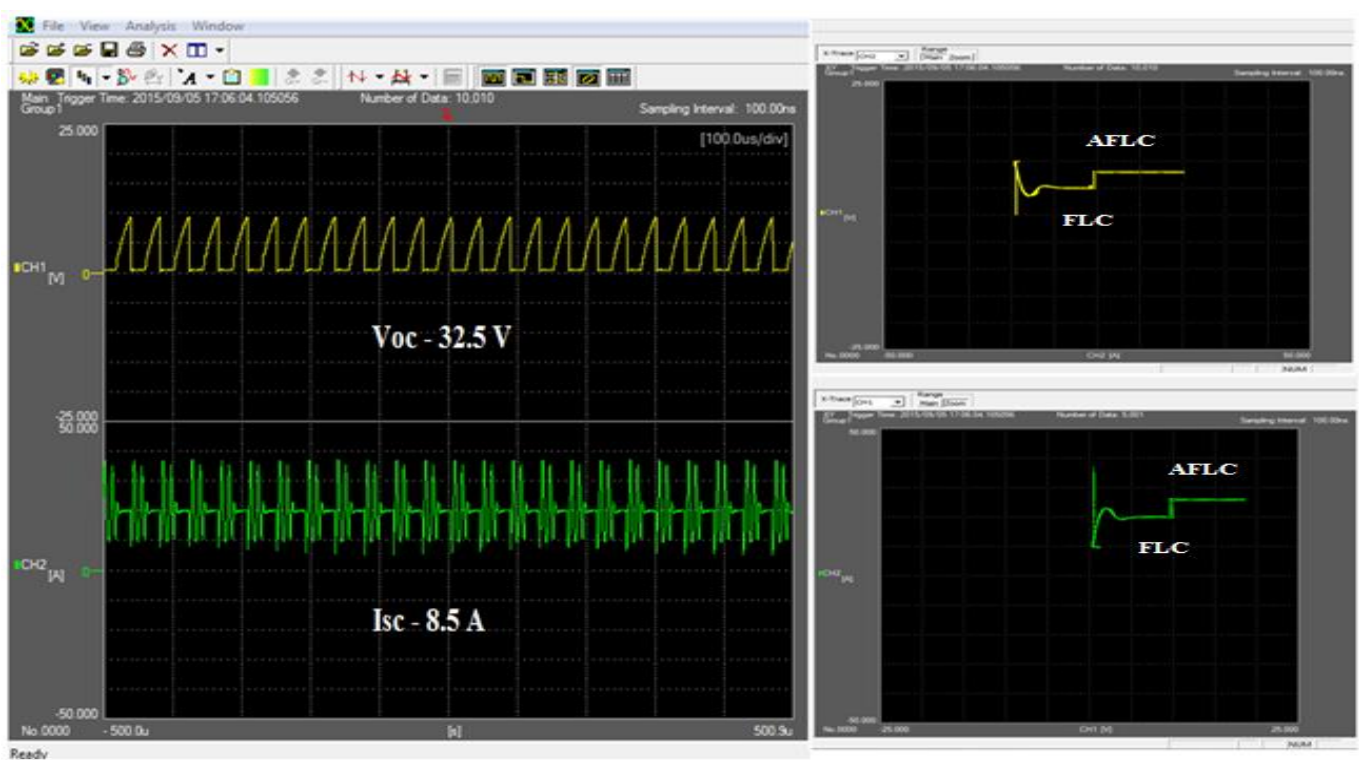

Figure 20. Experimental Results for PV Voltage and Current

The dynamic characteristics of PV array is measured using scope corder and it is shown in Figure 20, $\left(\mathrm{V}_{\mathrm{OC}}=32.5 \mathrm{~V}\right.$ and $\left.\mathrm{I}_{\mathrm{SC}}-8.5 \mathrm{~A}\right)$.

\subsection{AFLC based MPPT on FPGA}

The AFLC based MPPT is implemented on the FPGA board. Then, the DC-to-DC is hooked up and connected to FPGA. Figure 21, shows the logic circuit diagram in Xilinx 
ISE 14.1 software for the AFLC based MPPT and other components. The output of the controller is connected with a PWM module designed on the FPGA. The experimental PWM frequency of the modulating signal is about $50 \mathrm{KHz}$. Adjust duty cycle of boost converter for variable irradiance for AFLC MPPT as shown in Figure 22, The output of the PWM is examined using DSO by changing the values of the MPPT as shown in Figure 23.

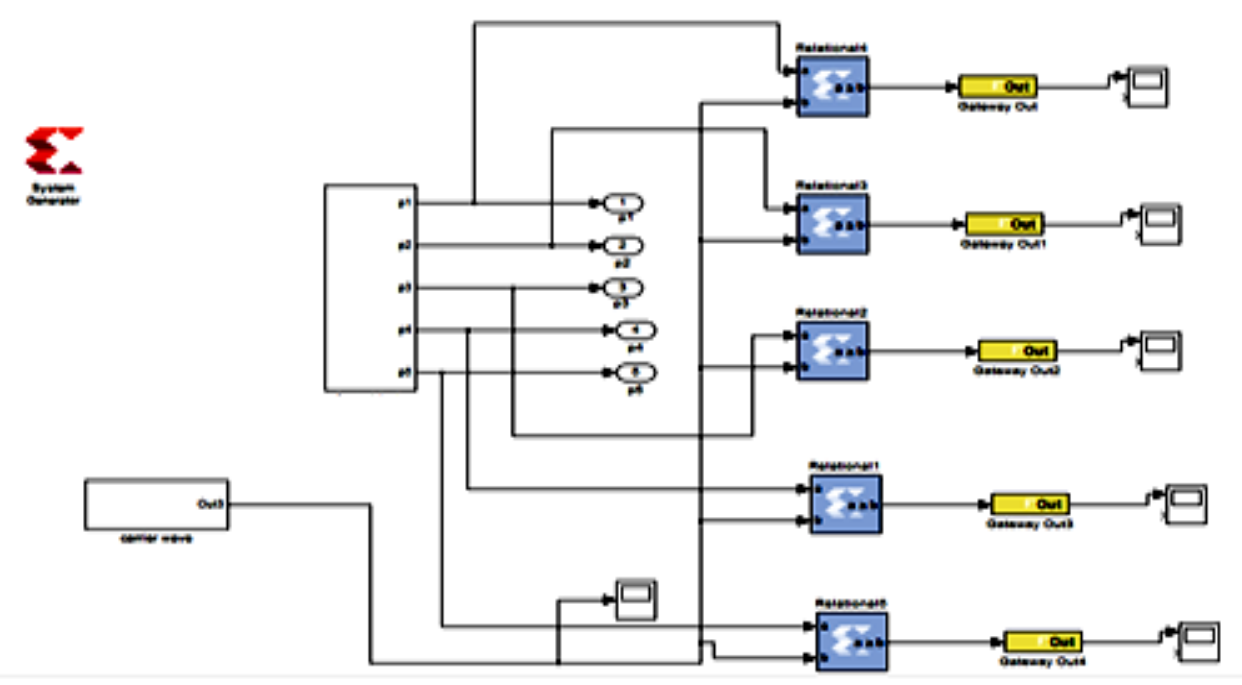

Figure 21. Logic Circuit Diagram for AFLC MPPT Using Xilinx

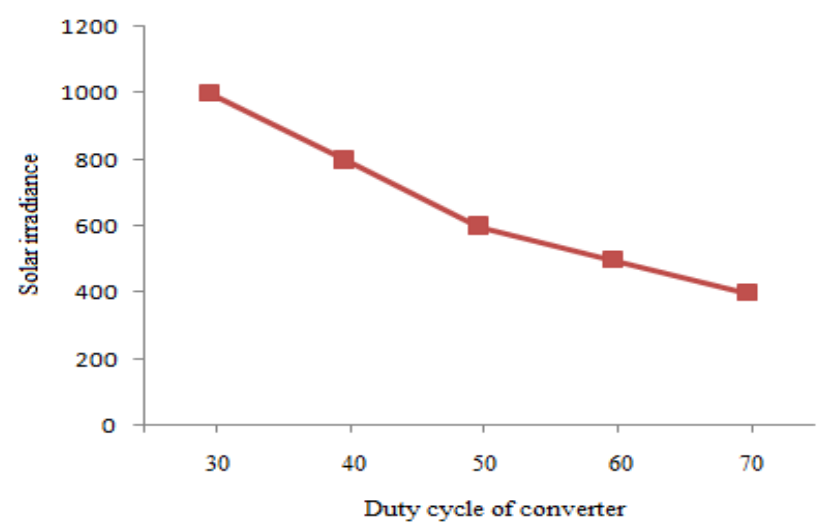

Figure 22. Experimental Results for Duty Cycle Vs. Solar Irradiance (AFLC) 
$30 \%$ duty cycle

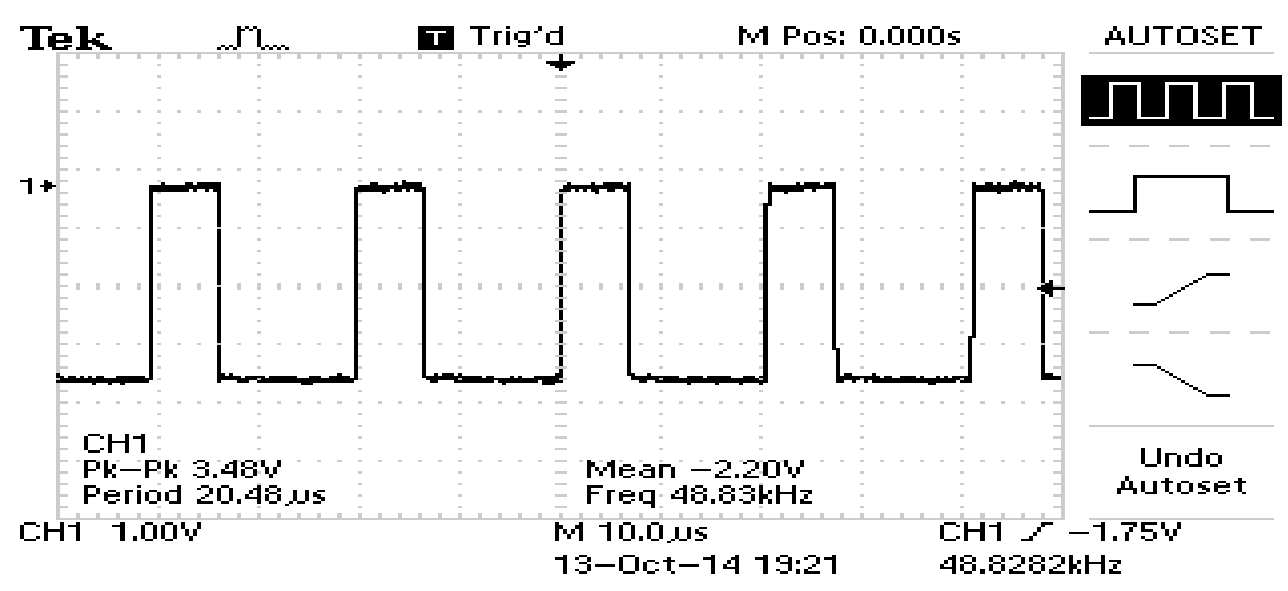

Figure (a)

$40 \%$ duty cycle

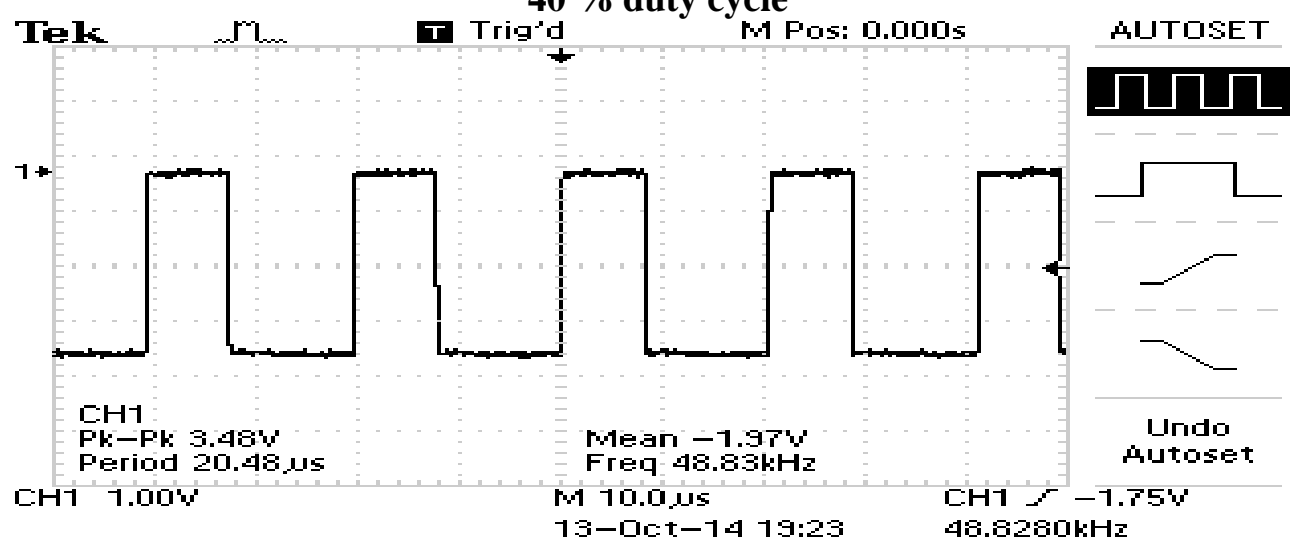

Figure (b)

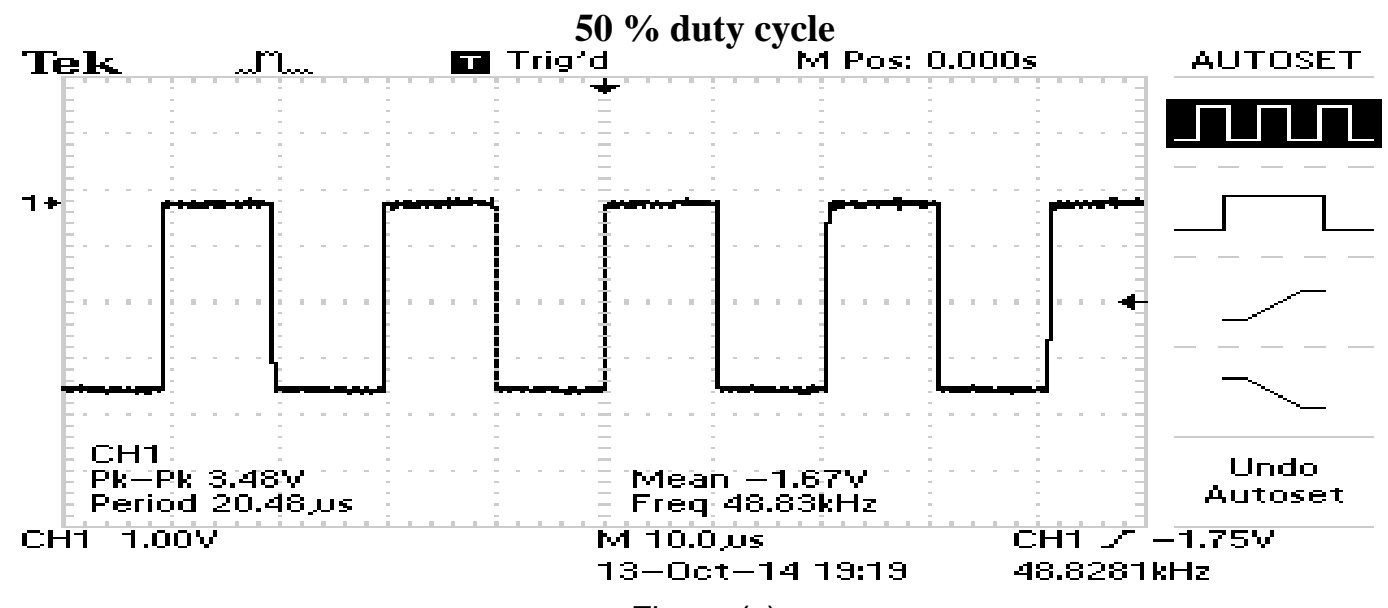

Figure (c) 


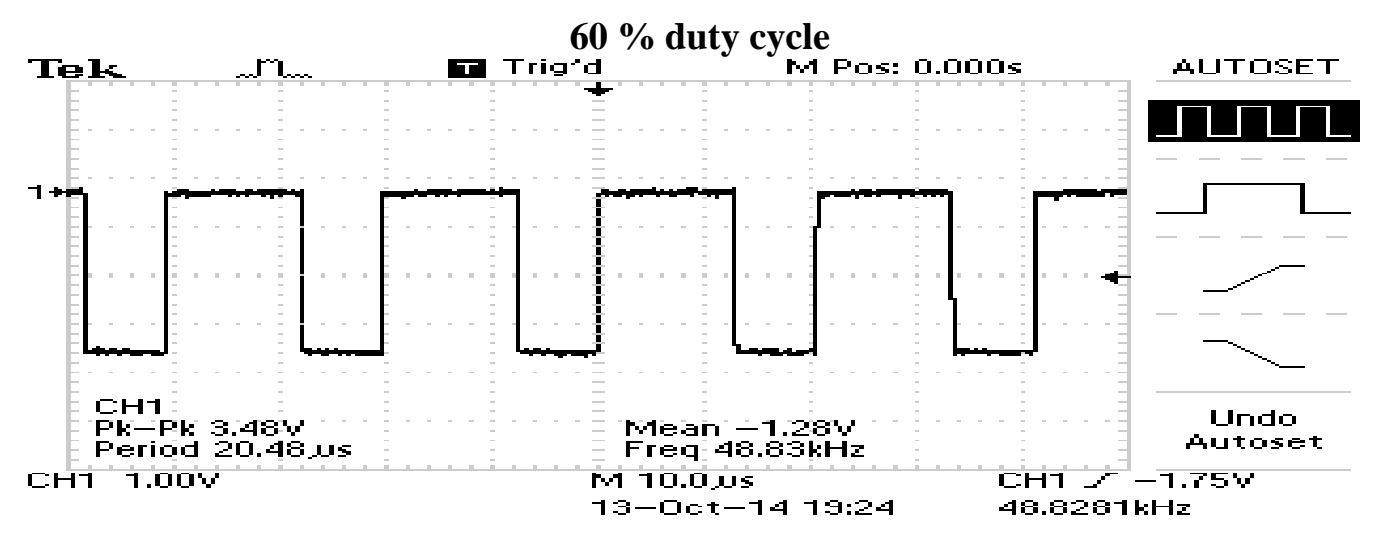

Figure (d)

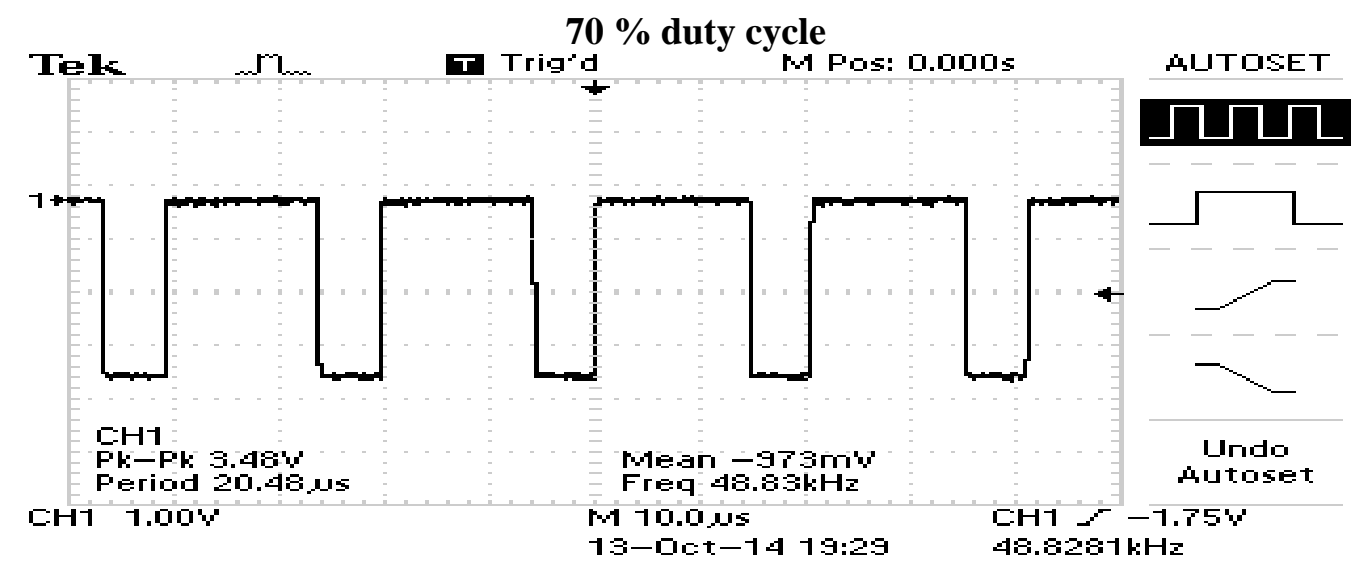

Figure (e)

Figure 23. (a)-(e) Change in the Duty Cycle of the PWM Output of Boost Converter (AFLC)

The input to the converter is about $28.2 \mathrm{~V}$ and output voltage obtained is about $62.4 \mathrm{~V}$ as shown in Figure 24. The MOSFET switches at $50 \%$ duty cycle.

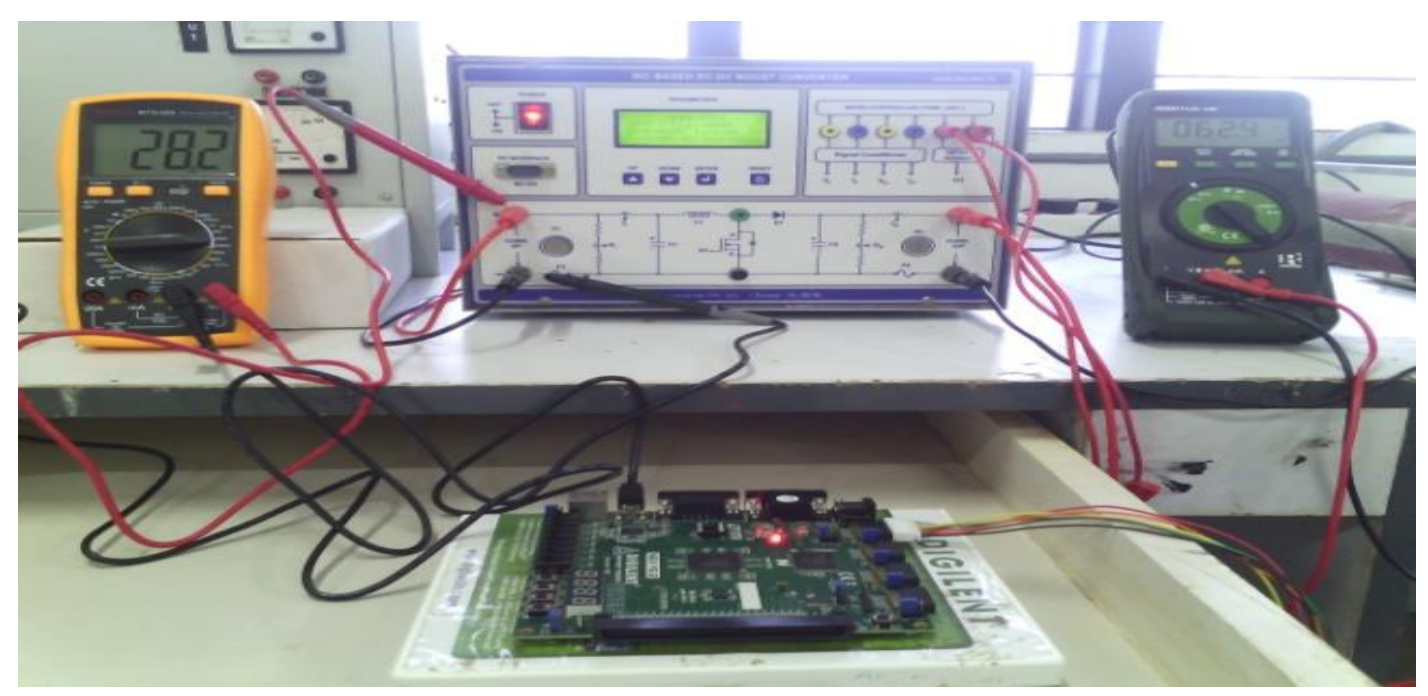

Figure 24. Input and Output Voltage of Step up Boost Converter using AFLC MPPT 
Table 6. Experimental Result of AFLC \& FLC MPPT Output Voltage and Input Current Ripple for Various Irradiance

\begin{tabular}{|c|c|c|c|c|c|c|}
\hline \multirow[t]{2}{*}{ S.NO } & \multirow[t]{2}{*}{$\begin{array}{c}\text { Solar } \\
\text { Irradiances } \\
\mathrm{W} / \mathrm{m}^{2}\end{array}$} & \multirow[t]{2}{*}{$\begin{array}{c}\text { Duty Cycle } \\
\%\end{array}$} & \multicolumn{2}{|c|}{$\begin{array}{c}\text { Output voltage ripple } \\
\%\end{array}$} & \multicolumn{2}{|c|}{$\begin{array}{c}\text { Input current ripple } \\
\%\end{array}$} \\
\hline & & & (AFLC) & (FLC) & (AFLC) & (FLC) \\
\hline 1 & 1000 & 30 & 1.3 & 2.6 & 1.65 & 3.15 \\
\hline 2 & 800 & 40 & 1.1 & 2.2 & 1.54 & 2.85 \\
\hline 3 & 600 & 50 & 0.9 & $1 . .9$ & 1.3 & 2.38 \\
\hline 4 & 500 & 60 & 0.83 & 1.8 & 1.25 & 2.16 \\
\hline 5 & 400 & 70 & 0.77 & 1.75 & 1.17 & 1.92 \\
\hline
\end{tabular}

Table 6, shows the comparison between AFLC and FLC MPPT. By employing AFLC MPPT, it was found that the output voltage and input current ripple are reduced compared to conventional FLC MPPT for various solar irradiance.

\section{Conclusion}

This paper has presented the adaptive fuzzy logic control for maximum power point tracking of photovoltaic system. The effectiveness of the proposed adaptive fuzzy MPPT controller has been demonstrated through simulation results carried out in MATLAB/Simulink. Maximum PV power achieved in AFLC is higher compared to the conventional FLC method. The FPGA implementation of the proposed control algorithms are presented and applied to a boost converter. It is observed that the AFLC MPPT results in reduced output voltage and input current ripple compared to FLC techniques. The experimental results show the effectiveness and feasibility of the proposed system and therefore the AFLC MPPT controller is a suitable technique for photovoltaic power generation system.

\section{References}

[1] M. S. Ngan and C. W. Tan, "A Study of Maximum Power Point Tracking Algorithms for Stand-alone Photovoltaic Systems", IEEE applied power electronics colloquium, (2011).

[2] V. Salas, E. Oli's, A. Barrado and A. La'zaro, "Review of the maximum power point tracking algorithms for stand-alone photovoltaic systems", Solar Energy Materials \& Solar Cells, (2006), pp. $1555-1578$.

[3] D. P. Hohm and M. E. Ropp, "Comparative Study of Maximum Power Point Tracking Algorithms," Programme of Photovoltaic Res. Application, vol. 11, (2003), pp. 47-62.

[4] Y. Kou, Y. Xia and Y. Ye, "Fast variable step-size maximum power point tracking method for photovoltaic systems", Renewable Sustainable Energy, vol. 7, no. 043126, (2015).

[5] S. Lalouni, D. Rekioua, T. Rekioua and E. Matagne, "Fuzzy logic control of stand-alone photovoltaic system with battery storage," Journal of Power Sources, vol. 193, (2009), pp. 899-907. 
[6] M. A. Farahat, M. A. Enany and A. Nasr, "Assessment of maximum power point tracking techniques for photovoltaic system applications", Renewable Sustainable Energy, vol. 7, no. 042702, (2015).

[7] S. N. Dash, R. K. Nema, D. Verma and S. Kumar, "A comprehensive assessment of maximum power point tracking techniques under uniform and non-uniform irradiance and its impact on photovoltaic systems: A review", Renewable Sustainable Energy, vol. 7, no. 063113, (2015).

[8] A. P. Bhatnagar and B. R. K. Nema, "Conventional and global maximum power point tracking techniques in photovoltaic applications: A review”, Renewable Sustainable Energy, vol. 5, no. 032701, (2013).

[9] H. A. Sher, A. F. Murtaza, A. Noman, K. E. Addoweesh and M. Chiaberge, "An intelligent control strategy of fractional short circuit current maximum power point tracking technique for photovoltaic applications", Renewable Sustainable Energy, vol. 7, no. 013114, (2015).

[10] J. Li and H. Wang, "Maximum Power Point Tracking of Photovoltaic Generation Based on the Fuzzy Control Method," IEEE SUPERGEN'09, (2009), pp. 1-6.

[11] Y. C. Kuo, T. J. Liang and J. F. Chen, "Novel Maximum-Power-Point-Tracking Controller for Photovoltaic Energy Conversion System," IEEE Transactions on Industrial Electronics, vol. 48, no. 3, (2001) June.

[12] Y. Zoua, Y. Yua, Y. Zhangb and J. Luc, "MPPT Control for PV Generation System Based on an Improved Incremental conductance Algorithm," Procedia Engineering, vol. 29, (2012), pp. 105-109.

[13] A. A. Diab and C. Sourkounis, "Variable Step Size P\&O MPPT Algorithm for PV Systems," 2010, 12th International Conference on Optimization of Electrical and Electronic Equipment, OPTIM, (2010).

[14] F. Chekired, C. Larbes, D. Rekioua and F. Haddad, "Implementation of a MPPT fuzzy controller for photovoltaic systems on FPGA circuit," Energy Procedia, vol. 6, (2011), pp. 541-549.

[15] F. Bouchafaa, I. Hamzaoui and A. Hadjammar, "Fuzzy Logic Control for the tracking of maximum power point of a PV system," Energy Procedia, vol. 6, (2011), pp. 633-642.

[16] G. Balasubramanian and S. Singaravelu, "Fuzzy logic controller for the maximum power point tracking in photovoltaic system," International Journal of Computer Applications, vol. 41, no. 12, (2012) March, pp. 0975-8887.

[17] E. Koutroulis, K. Kalaitzakis and N. C. Voulgaris, "Development of a Microcontroller-Based, Photovoltaic Maximum Power Point Tracking Control System,” IEEE transactions on power electronics, vol. 16, no. 1, (2001) January.

[18] N. Khaehintung, T. Wiangtong and P. Sirisuk, "FPGA Implementation of MPPT Using Variable StepSize P\&O Algorithm for PV Applications", IEEE International Symposium on Communication and Information, IEEE-ISCIT, vol. 06, (2006) pp. 212-215.

[19] H. Mekki, A. Mellit, S. A. Kalogirou, A. Messai and G. Furlan, "FPGA-Based implementation of a real time photovoltaic module simulator", Progress in Photovoltaics: Research and Application, (2010), pp. 115-127.

[20] A. Messai, A. Mellit, A. Guessoum and S. A. Kalogirou, "Maximum power point tracking using a GA optimized fuzzy logic controller and its FPGA implementation", Solar energy, (2010).

[21] T. Salmi, M. Bouzguenda, A. Gastli and A. Masmoudi, "Matlab/Simulink based modelling of solar photovoltaic cell," International Journal of Renewable Energy Research, vol. 2, no. 2, (2012), pp. 213 218.

[22] S. S. Letha, T. Thakur, J. Kumar, D. Karanjkar and S. Chatterji, "Design and Real Time Simulation of Artificial Intelligent Based MPP Tracker for Photo-Voltaic System”, Proc. ASME, Energy, vol. 6, (2014) November 14.

[23] M. Averbukh, Y. B. Galim and A. Uhananov, "Development of a Quick Dynamic Response Maximum Power Point Tracking Algorithm for Off-Grid System With Adaptive Switching (On-Off) Control of dc/dc Converter Journal Solar Energy Engineering”, (2012). 